\title{
RESENHA
}

\section{TABU: SEXO, IDENTIDADE E SUBJETIVIDADE ERÓTICA NO CAMPO DE TRABALHO ANTROPOLÓGICO}

Resenha de: Kulick, M., \& Willson, M. (Eds.). (1996). Taboo: sex, identity and erotic subjectivity in anthropological fieldwork (2a ed.). [Tabu: sexo, identidade e subjetividade erótica no campo de trabalho antropológico]. London: Routledge.

S exo sempre foi um tabu e, ao que parece, tardará a deixar de sê-lo. EnStretanto, de maneira sutil, porém audaciosa, Kulick e Willson optaram por romper a "barreira do silêncio" e compilar no livro Tabu: sexo, identidade e subjetividade erótica no trabalho de campo antropológico (Taboo: sex, identity and erotic subjectivity in anthropological fieldwork) artigos de autoria de alguns antropólogos que se dispuseram a colaborar nessa pesquisa sobre fantasias, relações eróticas e encontros sexuais dos próprios antropólogos pesquisadores com membros das sociedades nas quais conduziam suas pesquisas.

Apesar de se preocuparem com a vida sexual das comunidades analisadas, os estudiosos tendem a manter os lábios selados quanto à evidência da sua própria sexualidade. Adotam essa postura em relação à própria sexualidade, sobretudo, em razão do modo como a ciência antropológica se desenvolveu e é preponderantemente compreendida, nessa particularidade, até os dias de hoje. 
Parece existir um determinado tipo de regra não escrita, não falada e, principalmente, não questionada sobre a ética sexual em trabalho de campo, absorvida, de alguma forma, por todos os estudantes de antropologia durante o processo de graduação. Regra essa que pode ser sintetizada em uma única expressão: NÃO FAÇA. (Kulick \& Willson, 1996, p. 10)

No entanto, na esteira da forte influência causada pela ousadia de Malinowsky - antropólogo que, em 1967, publicou um diário, no qual dêscreveu seus sonhos eróticos, fantasias e frustrações sexuais ocorridas quando pesquisava grupos culturalmente distintos -, Kulick e Willson (1996) reuniram diversos registros relacionados a situações de estudos in loco, que vão desde o amor idílico vivido em um romance até a violência sexual máxima, concretizada pelo estupro.

Bolton, no capítulo intitulado "Tricks, friends and lovers: erotic encounters in the field”, discorre sobre a importância simbólica e erótica passíveis de representação a partir de um determinado local. Além disso, descreve a interação dos desejos pessoais com o espírito etnográfico, narrada em virtude de seu trabalho realizado com homoafetivos e portadores do vírus HIV.

No capítulo denominado "Rape in the field: reflections from a survivor”, uma antropóloga, que adotou o pseudônimo Eva Moreno, obviamente em razão de ter sido vítima do fato já enunciado no título do ensaio, expõe a combinação entre as diferenças culturais, o jogo de poder entre gêneros (feminino e masculino) e as suas, na época, inexperiência e ingenuidade, como possíveis responsáveis pela traumática vivência de ter sido estuprada, quando pesquisadora, em uma cidadela africana. A temática da violência também é explorada por Gearing no capítulo "Fear and loving in the West Indies: research from the heart (as well as the head)", no qual é enfatizada a dinâmica da agressão sexual em relacionamentos heterossexuais. Todavia também, revela em seu texto, o lado dócil da vida, na localidade de Saint Vincent, onde conheceu um de seus assistentes, por quem se apaixonou e com quem se casou.

Taboo, enfim, congrega uma série de oito ensaios, marcados por uma linguagem narrativa, que se preocupam predominantemente com a exposição dos fatos experimentados pelos próprios pesquisadores. Em outras pala- 


\section{Resenha}

vras, o livro, que segue o destemido exemplo de Malinowsky, reacende a luz no escuro túnel que envolve os antropólogos e a sexualidade. Desse modo, fornece farto material ao estudioso da Psicologia, permitindo-lhe refletir sobre a maneira pela qual os papéis de gênero e a identidade sexual dos próprios pesquisadores podem afetar os tipos de sexualidade expressas em diferentes culturas.

\section{Referência}

Kulick, D., \& Willson, M. (1996). Taboo: sex, identity and erotic subjectivity in anthropological fieldwork (2a ed.). London: Routledge.

Leticia Domingues Bertuzzi ${ }^{1}$

Pontifícia Universidade Católica do Rio Grande do Sul

1 Graduanda do curso de Psicologia da PUC-RS e bolsista CNPq do grupo de pesquisa "Estudos Culturais e Teorias Contemporâneas", coordenado pela Profa. Dra. Neusa Guareschi. 